\title{
Article \\ Seaweeds as Valuable Sources of Essential Fatty Acids for Human Nutrition
}

\author{
Carolina P. Rocha ${ }^{1}(\mathbb{D})$, Diana Pacheco ${ }^{1}\left(\mathbb{D}\right.$, João $_{\text {Cotas }}{ }^{1}\left(\mathbb{D}\right.$, João C. Marques ${ }^{1}$, Leonel Pereira ${ }^{1}(\mathbb{D})$ and \\ Ana M. M. Gonçalves $1,2, * \mathbb{D}$ \\ 1 University of Coimbra, MARE-Marine and Environmental Sciences Centre, Department of Life Sciences, \\ Calçada Martim de Freitas, 3000-456 Coimbra, Portugal; carolina.vpr@gmail.com (C.P.R.); \\ diana.pacheco@uc.pt (D.P.); jcotas@uc.pt (J.C.); jcmimar@ci.uc.pt (J.C.M.); leonel.pereira@uc.pt (L.P.) \\ 2 Department of Biology and CESAM, University of Aveiro, 3810-193 Aveiro, Portugal \\ * Correspondence: amgoncalves@uc.pt; Tel.: +351-239-240-700 (ext. 262-286)
}

Citation: Rocha, C.P.; Pacheco, D.; Cotas, J.; Marques, J.C.; Pereira, L.; Gonçalves, A.M.M. Seaweeds as Valuable Sources of Essential Fatty Acids for Human Nutrition. Int. J. Environ. Res. Public Health 2021, 18 4968. https://doi.org/10.3390/ ijerph18094968

Academic Editor: Paul B. Tchounwou

Received: 2 April 2021

Accepted: 30 April 2021

Published: 7 May 2021

Publisher's Note: MDPI stays neutral with regard to jurisdictional claims in published maps and institutional affiliations.

Copyright: (c) 2021 by the authors. Licensee MDPI, Basel, Switzerland This article is an open access article distributed under the terms and conditions of the Creative Commons Attribution (CC BY) license (https:// creativecommons.org/licenses/by/ $4.0 /)$.

\begin{abstract}
The overexploitation of terrestrial habitats, combined with the ever-growing demand for food, has led to the search for alternative food sources. The importance of seaweeds as food sources has been growing, and their potential as sources of fatty acids (FA) make seaweeds an interesting feedstock for the food and nutraceutical industries. The aim of this study is to assess the potential of five red seaweeds (Asparagospis armata, Calliblepharis jubata, Chondracanthus teedei var. lusitanicus, Gracilaria gracilis, and Grateloupia turuturu) and three brown seaweeds (Colpomenia peregrina, Sargassum muticum and Undaria pinnatifida), harvested in central Portugal, as effective sources of essential FA for food or as dietary supplements. FA were extracted from the biomass, transmethylated to methyl esters, and analyzed through gas chromatography-mass spectrometry. G. gracilis presented the highest content of saturated fatty acids (SFA) $\left(41.49 \mathrm{mg} \cdot \mathrm{g}^{-1}\right)$, whereas C. jubata exhibited the highest content of highly unsaturated fatty acids (HUFA) $\left(28.56 \mathrm{mg} \cdot \mathrm{g}^{-1}\right)$; the three G. turuturu life cycle stages presented prominent SFA and HUFA contents. Omega-6/omega-3 ratios were assessed and, in combination with PUFA+HUFA/SFA ratios, it is suggested that $C$. jubata and $U$. pinnatifida may be the algae with highest nutraceutical potential, promoting health benefits and contributing to a balanced dietary intake of fatty acids.
\end{abstract}

Keywords: indigenous and non-indigenous seaweeds; marine resources; fatty acids; nutritional value; human health promoter

\section{Introduction}

Lipids are essential nutrients for human health. However, it is necessary to ensure a balanced intake in appropriate quantities and in combination with other important nutrients, such as vitamins, carbohydrates, proteins, and minerals [1,2]. Lipids' primary role is to provide energy, but they are also needed for the maintenance of cell membrane integrity and hormone production [3]. Moreover, lipids are essential to transport and absorb fat-soluble vitamins (i.e., A, D, E, and K).

Diseases such as obesity, diabetes, dyslipidemia, and cardiovascular-related co-morbidities have all been linked to a high saturated lipid intake, mostly saturated fatty acids (SFA) [4,5]. Nowadays, fast food is one of the most consumed food types in the world, and contains a high amount of saturated fats. As a consequence, harmful effects on human health are observed related to this type of diet [6,7].

There is a growing need to evaluate novel food sources that do not imply the overexploitation of terrestrial ecosystems [8] to release some pressure over these systems. Therefore, seaweeds present an innovative feedstock for the food market as a fatty acid (FA) source. Despite the low total lipid concentration that seaweeds contain, they have a significant amount of essential unsaturated fatty acids (UFA), which are pivotal for human welfare [6,9]. Particularly, seaweeds synthesize omega-3 and -6 ( $\omega-3$ and $\omega-6$, respectively), 
polyunsaturated fatty acids (PUFA), and highly unsaturated fatty acids (HUFA), as well as monounsaturated fatty acids (MUFA) [10], which have already been demonstrated to play a key role in human metabolism (essential fatty acids-EFA), being involved in cell growth and metabolic pathways, contrarily to SFA, which serve mainly as energy sources [11].

The lipidic profile of seaweeds differs between species [6], and thus, there is a need to evaluate different seaweed species to understand their potential for industrial application and exploitation, such as food products or as dietary supplements [9,12].

The overgrowth of non-indigenous seaweed species is currently endangering aquatic systems, threatening coastal fauna, flora, and the ecosystem services provided $[13,14]$. Several non-indigenous macroalgae have been reported as serious threats to the marine environment on the Iberian Peninsula, including the red seaweeds Asparagopsis armata and Grateloupia turuturu, as well as the brown seaweeds Sargassum muticum, Undaria pinnatifida, and Colpomenia peregrina [15]. Therefore, not only native species, but also non-indigenous species, should be evaluated for biotechnological applications and economic value of algal resources [16-18].

Both FA concentration and profile differ among the variation of biotic and abiotic parameters, as well as with genetic characteristics from each algae [19-21]. Thus, the life cycle of each seaweed can also influence the FA content and characterization of algae. This is relevant, particularly, in red seaweeds which present a triphasic life cycle, and each phase has taxonomic characteristics that enables their distinctiveness [22-24]. For instance, the red seaweeds Grateloupia turuturu and Chondracanthus teedei var. lusitanicus synthesize different sulfated polysaccharides, according to their life cycle phase [25-28]. However, to the best of our knowledge, there is no published literature reporting if that also happens regarding their lipid (in particular, fatty acid) content. Still, to explore industrially these marine resources, it is important to understand if their FA composition also varies during the life cycle phase.

On average, seaweeds have a lipid yield between $0.61 \%$ and $4.15 \%$ dry weight (DW). However, some seaweed species can present higher values, being considered a good source of unsaturated fatty acids [29].

Undeniably, micro and macroalgae are fundamental organisms for the introduction of long-chain PUFA in food webs, as they possess cellular mechanisms to undergo FA elongation, with the production of molecules containing from 14 to 24 carbons [30,31], an ability that most consumers, for example, do not present.

These PUFAs can be beneficial for human health if the ratio $\omega-6 / \omega-3$ is taken into account in functional foods and nutraceuticals [31]. The impact of these fatty acids on human gene expression is well understood and the $\omega-6 / \omega-3$ fatty acid ratio is a critical metric for assessing the benefits of PUFAs. A previous study showed that a $3 / 1$ to $5 / 1$ $\omega-6 / \omega-3$ fatty acid ratio lowers the risk of breast, prostate, colon, and renal cancers [32,33]. In other cases, the $\omega-6 / \omega-3$ fatty acid ratio of $2 / 1$ to $3 / 1$ was found to minimize inflammation in rheumatoid arthritis patients. A 5/1 ratio, for example, was shown to be effective in asthma patients [32]. In contrast, a fatty acid ratio of $10 / 1$ and higher has been linked to negative outcomes [32,33].

This study aims to evaluate and perform a comparative analysis of the potential of eight algae species harvested from the Central region of Portugal to determine the most suitable seaweeds as a source of FA that can be used as food or a dietary supplement.

\section{Materials and Methods}

\subsection{Seaweed Harvesting}

Throughout the year of 2020, five red seaweeds (Asparagospis armata, Calliblepharis jubata, Chondracanthus teedei var. lusitanicus Gracilaria gracilis, and Grateloupia turuturu) and three brown seaweeds (Colpomenia peregrina, Sargassum muticum and Undaria pinnatifida) were harvested in two Portuguese seashores (Buarcos Bay, Figueira da Foz, and Quebrado Beach, Peniche) (Table 1). Following that, seaweeds were transported to the laboratory in plastic bags in a coolbox and frozen at $-20{ }^{\circ} \mathrm{C}$ until further analysis. 
Table 1. Seaweed harvesting sites and dates.

\begin{tabular}{lccc}
\hline \multicolumn{1}{c}{ Seaweed Species } & Location & GPS Location & Harvesting Date \\
\hline \multicolumn{1}{c}{ Rhodophyta (red seaweed) } & & & \\
Asparagopsis armata * & Quebrado Beach & $39.368258,-9.372303$ & $20 / 10 / 2020$ \\
Calliblepharis jubata & Buarcos Bay & $40.165867,-8.885556$ & $19 / 10 / 2020$ \\
Chondracanthus teedei var. lusitanicus & Buarcos Bay & $40.165867,-8.885556$ & $27 / 05 / 2020$ \\
Gracilaria gracilis & Buarcos Bay & $40.165867,-8.885556$ & $19 / 10 / 2020$ \\
Grateloupia turuturu * & Buarcos Bay & $40.165867,-8.885556$ & $13 / 01 / 2020$ \\
\hline$\quad$ Ochrophyta (brown seaweed) & & & \\
Colpomenia peregrine * & Quebrado Beach & $39.368258,-9.372303$ & $20 / 10 / 2020$ \\
Sargassum muticum * & Buarcos Bay & $40.165867,-8.885556$ & $19 / 10 / 2020$ \\
Undaria pinnatifida * & Buarcos Bay & $40.165867,-8.885556$ & $13 / 01 / 2020$ \\
\hline${ }^{*}$ non-indigenous seaweed species. & & &
\end{tabular}

After that, the seaweed biomass was washed with filtered seawater to remove sand, epiphytes, and other detritus. Due to the biochemical profile variation according to the life cycle, the red seaweed G. turuturu and C. teedei var. lusitanicus were differentiated according to their generation through a binocular magnifying glass.

The biomass was then washed with distilled water to eliminate the salt content of seawater, placed in plastic trays, and dried for $48 \mathrm{~h}$ at $60^{\circ} \mathrm{C}$ in an air-forced oven (Raypa DAF-135, R. Espinar S.L., Barcelona, Spain). Following this, the biological samples were milled $(<1 \mathrm{~cm}$ ) with a commercial grinder (Taurus aromatic, Oliana, Spain) and stored in Eppendorfs in a dark and dry place at room temperature.

\subsection{Fatty Acid Analysis}

Fatty acids were extracted from dry algal biomass and transmethylated to fatty acid methyl esters (FAMEs) for analysis as described by Gonçalves et al. (2012) [34] and stored in liquid form at $-80^{\circ} \mathrm{C}$ until analysis.

FAMEs identification was performed by Gas chromatography-Mass spectrometry (GC-MS), with resort to a Thermo Scientific Trace 1310 Network (Waltham, MA, USA) equipment, equipped with TR-FFAP column of $0.32 \mathrm{~mm}$ internal diameter, $0.25 \mu \mathrm{m}$ film thickness, and $30 \mathrm{~m}$ long. The sample $(0.60 \mu \mathrm{L})$ was injected at splitless mode, at an injector temperature of $250{ }^{\circ} \mathrm{C}$, lined with a split glass liner of $4.0 \mathrm{~mm}$ i.d. The initial oven temperature was $80^{\circ} \mathrm{C}$, following a linear temperature increase of $25^{\circ} \mathrm{C} \mathrm{min}-1$ to $160^{\circ} \mathrm{C}$, followed by another ramp of $2{ }^{\circ} \mathrm{C} \mathrm{min}-1$ to $210^{\circ} \mathrm{C}$ and finally an increase of $40{ }^{\circ} \mathrm{C} \mathrm{min}{ }^{-1}$ until a final temperature of $230^{\circ} \mathrm{C}$ was reached and maintained for $10 \mathrm{~min}$. Helium at a flow rate of $1.4 \mathrm{~mL} \mathrm{~min}^{-1}$ was used as carrier gas. A Thermo Scientific ISQ 7000 Network Mass Selective Detector at scanning $m / z$ ranges specific for fatty acids in Selected Ion Monitoring (SIM) mode acquisition was used. The detector starts operating $3.5 \mathrm{~min}$ after injection, corresponding to solvent delay. The injector ion source and transfer line were maintained at $240{ }^{\circ} \mathrm{C}$ and $230^{\circ} \mathrm{C}$, respectively. Integration of FAME peaks were carried out using the equipment's software. Identification of each peak was performed by retention time and mass spectrum of each FAME, comparing to the Supelco ${ }^{\circledR} 37$ component FAME mix (Sigma-Aldrich, Steinheim, Germany). Quantification of FAMEs was performed as described in Gonçalves et al. (2012) [34].

\subsection{Statistical Analysis}

The fatty acid profiles of the seaweed species studied were statistically analyzed and compared through non-metric multidimensional scaling (n-MDS), associated to analysis of similarities (ANOSIM) and similarity percentage analysis (SIMPER), to assess the similarities and the average dissimilarity between groups, including the contribution (percentage) of each fatty acid to dissimilarities between groups, as well as analysis of variance (ANOVA), to assess differences in the studied components between species.

\section{Results}

The calculated moisture percentage of each algae species is presented in Table 2. 
Table 2. Moisture (expressed in percentage) of Sargassum muticum, Undaria pinnatifida, Colpomenia peregrina, Gracilaria gracilis, Calliblepharis jubata and Asparagopsis armata, Chondracanthus teedei var. Lusitanicus (MG—male gametophyte, FG—female gametophyte, and T-tetrasporophyte), and Grateloupia turuturu (FrG—fructified gametophyte, $\mathrm{nFrG}$-non-fructified gametophyte, and T—tetrasporophyte).

\begin{tabular}{cc}
\hline Species & Moisture (\%) \\
\hline S. muticum & 87.22 \\
U. pinnatifida & 86.84 \\
C. peregrina & 91.25 \\
G. gracilis & 49.49 \\
C. jubata & 89.13 \\
A. armata & 87.22 \\
C. teedei $(\mathrm{MG})$ & 85.86 \\
C. teedei (FG) & 85.43 \\
C. teedei (T) & 84.35 \\
G. turuturu (FrG) & 86.78 \\
G. turuturu (nFrG) & 87.69 \\
G. turuturu (T) & 88.24 \\
\hline
\end{tabular}

Fatty acid analysis allowed the identification of SFA, MUFA, PUFA, and HUFA in the studied species, with a particular interest in the omega- 3 fatty acids encountered, as represented in Tables 3 and 4. In terms of total fatty acids per gram of dried algae, Sargassum muticum was the species presenting the highest value, with the contribution of HUFA for the total FA content being particularly high (of $28 \%$ of total FA). Saturated fatty acids were the most abundant class of FA in most species, except for Undaria pinnatifida and Calliblepharis jubata, where HUFA was the most abundant class. All algae species presented a considerably low $\omega-6 / \omega-3$ ratio, with the highest of 0.15 in S. muticum and the lowest of 0.01 in C. jubata.

Table 3. Fatty acid profile of each fatty acid (expressed in $\mathrm{mg} \cdot \mathrm{g}^{-1}$ of dried algae) of Sargassum muticum, Undaria pinnatifida, Colpomenia peregrina, Gracilaria gracilis, Calliblepharis jubata, and Asparagopsis armata. $\alpha$-LA alpha linoleic acid; $\gamma$-LA—gamma linoleic acid; ARA—arachidonic acid; EPA—eicosapentaenoic acid; DHA—docosahexaenoic acid. Results are expressed in mean \pm standard deviation. The sum of fatty acids' (FA) content that compose each class (SFA—saturated fatty acids; MUFA - monounsaturated fatty acids; PUFA—-polyunsaturated fatty acids; HUFA—highly unsaturated fatty acids), the ratio of omega 6/omega 3 and the $N$-diversity in FA molecules have been highlighted with bold format in the respective table lines.

\begin{tabular}{|c|c|c|c|c|c|c|}
\hline & S. muticum & U. pinnatifida & C. peregrina & G. gracilis & C. jubata & A. armata \\
\hline C16:0 & $20.89 \pm 0.72$ & $11.51 \pm 0.01$ & $18.24 \pm 0.31$ & $40.46 \pm 0.23$ & $15.94 \pm 0.73$ & $26.39 \pm 1.19$ \\
\hline C17:0 & $0.29 \pm 0.03$ & $0.00 \pm 0.00$ & $0.00 \pm 0.00$ & $0.00 \pm 0.00$ & $2.24 \pm 0.05$ & $0.00 \pm 0.00$ \\
\hline C18:0 & $0.43 \pm 0.03$ & $0.64 \pm 0.02$ & $0.00 \pm 0.00$ & $1.03 \pm 0.13$ & $0.17 \pm 0.03$ & $0.71 \pm 0.10$ \\
\hline C24:0 & $0.45 \pm 0.05$ & $0.00 \pm 0.00$ & $0.00 \pm 0.00$ & $0.00 \pm 0.00$ & $0.00 \pm 0.00$ & $0.00 \pm 0.00$ \\
\hline$\sum$ SFA & 22.06 & 12.15 & 18.24 & 41.49 & 18.35 & 27.10 \\
\hline C15:1 & $3.15 \pm 0.15$ & $2.44 \pm 0.10$ & $7.72 \pm 0.14$ & $5.64 \pm 0.47$ & $3.28 \pm 0.14$ & $8.53 \pm 0.29$ \\
\hline C16:1 & $7.43 \pm 0.15$ & $1.66 \pm 0.06$ & $2.66 \pm 0.05$ & $1.13 \pm 0.09$ & $2.14 \pm 0.20$ & $3.60 \pm 0.18$ \\
\hline C18:1 & $7.84 \pm 0.24$ & $6.21 \pm 0.11$ & $11.24 \pm 0.28$ & $9.21 \pm 0.23$ & $4.42 \pm 0.63$ & $6.77 \pm 0.56$ \\
\hline$\sum$ MUFA & 18.42 & 10.31 & 21.62 & 15.98 & 9.83 & 18.90 \\
\hline C18:2 & $4.67 \pm 0.23$ & $3.87 \pm 0.08$ & $0.96 \pm 0.06$ & $0.74 \pm 0.06$ & $0.27 \pm 0.05$ & $0.78 \pm 0.04$ \\
\hline C18:3 ( $\alpha-\mathrm{LA})$ & $6.23 \pm 0.23$ & $7.51 \pm 0.42$ & $1.53 \pm 0.01$ & $0.00 \pm 0.00$ & $0.00 \pm 0.00$ & $0.80 \pm 0.09$ \\
\hline C18:3 ( $\gamma$-LA) & $3.01 \pm 0.24$ & $12.33 \pm 0.67$ & $1.92 \pm 0.09$ & $0.00 \pm 0.00$ & $0.00 \pm 0.00$ & $0.62 \pm 0.01$ \\
\hline$\sum$ PUFA & 13.92 & 23.71 & 4.40 & 0.74 & 0.27 & 2.21 \\
\hline C20:4 (ARA) & $0.00 \pm 0.00$ & $0.00 \pm 0.00$ & $0.00 \pm 0.00$ & $0.00 \pm 0.00$ & $0.00 \pm 0.00$ & $0.77 \pm 0.05$ \\
\hline C20:5 (EPA) & $13.83 \pm 0.48$ & $13.15 \pm 0.02$ & $2.59 \pm 0.00$ & $5.58 \pm 0.09$ & $6.22 \pm 0.22$ & $2.43 \pm 0.01$ \\
\hline C22:6 (DHA) & $7.33 \pm 0.72$ & $8.55 \pm 0.37$ & $5.80 \pm 0.29$ & $0.00 \pm 0.00$ & $22.34 \pm 0.63$ & $8.83 \pm 0.49$ \\
\hline$\sum$ HUFA & 21.17 & 21.70 & 8.39 & 5.58 & 28.56 & 12.03 \\
\hline$\sum$ FA & 75.56 & 67.86 & 52.65 & 63.80 & 57.01 & 60.23 \\
\hline$\omega-6 / \omega-3$ & 0.15 & 0.09 & 0.08 & 0.13 & 0.01 & 0.12 \\
\hline$N$ & 12 & 10 & 9 & 7 & 9 & 11 \\
\hline
\end{tabular}


Table 4. Fatty acid profile of each fatty acid (expressed in $\mathrm{mg} \cdot \mathrm{g}^{-1}$ of dried algae) of Chondracanthus teedei var. lusitanicus (MG—male gametophyte, FG—-female gametophyte, and T-tetrasporophyte) and Grateloupia turuturu (FrG—fructified gametophyte, $\mathrm{nFrG}$-non-fructified gametophyte, and T—tetrasporophyte). Results are expressed in mean \pm standard deviation. The sum of fatty acids' (FA) content that compose each class (SFA—saturated fatty acids; MUFA-monounsaturated fatty acids; PUFA - polyunsaturated fatty acids; HUFA—highly unsaturated fatty acids), the ratio of omega 6/omega 3 and the $N$-diversity in FA molecules have been highlighted with bold format in the respective table lines.

\begin{tabular}{|c|c|c|c|c|c|c|}
\hline & C. teedei (MG) & C. teedei (FG) & C. teedei $(\mathrm{T})$ & G. turuturu (FrG) & G. turuturu (nFrG) & G. turuturu $(\mathrm{T})$ \\
\hline $\mathrm{C} 16: 0$ & $20.29 \pm 8.45$ & $1.66 \pm 4.36$ & $17.46 \pm 0.63$ & $13.59 \pm 14.20$ & $11.84 \pm 5.65$ & $15.75 \pm 5.41$ \\
\hline $\mathrm{C} 17: 0$ & $0.00 \pm 0.00$ & $0.00 \pm 0.00$ & $0.00 \pm 0.00$ & $0.00 \pm 0.00$ & $0.00 \pm 0.00$ & $0.00 \pm 1.08$ \\
\hline C18:0 & $0.50 \pm 0.04$ & $0.12 \pm 0.07$ & $0.32 \pm 0.02$ & $2.69 \pm 0.49$ & $2.34 \pm 0.00$ & $3.12 \pm 0.10$ \\
\hline C24:0 & $0.26 \pm 0.20$ & $0.15 \pm 0.04$ & $0.00 \pm 0.00$ & $0.00 \pm 0.00$ & $0.00 \pm 0.00$ & $0.00 \pm 0.00$ \\
\hline$\sum$ SFA & 21.16 & 1.93 & 17.78 & 16.28 & 14.18 & 18.87 \\
\hline C15:1 & $2.41 \pm 0.93$ & $0.21 \pm 0.48$ & $2.63 \pm 0.34$ & $0.00 \pm 0.00$ & $0.00 \pm 0.00$ & $0.00 \pm 0.00$ \\
\hline $\mathrm{C} 16: 1$ & $0.84 \pm 0.03$ & $0.12 \pm 0.10$ & $1.20 \pm 0.06$ & $0.05 \pm 0.84$ & $0.05 \pm 0.88$ & $0.06 \pm 0.81$ \\
\hline C18:1 & $3.08 \pm 2.71$ & $0.44 \pm 1.29$ & $4.99 \pm 0.28$ & $0.23 \pm 3.02$ & $0.20 \pm 3.51$ & $0.26 \pm 3.37$ \\
\hline$\sum$ MUFA & 6.32 & 0.77 & 8.82 & 0.28 & 0.24 & 0.33 \\
\hline C18:2 & $0.41 \pm 0.01$ & $0.14 \pm 0.13$ & $0.38 \pm 0.02$ & $0.07 \pm 0.27$ & $0.06 \pm 0.34$ & $0.08 \pm 0.35$ \\
\hline $\mathrm{C} 18: 3(\alpha-\mathrm{LA})$ & $0.00 \pm 0.00$ & $0.00 \pm 0.00$ & $0.00 \pm 0.00$ & $0.02 \pm 0.64$ & $0.02 \pm 0.52$ & $0.03 \pm 0.65$ \\
\hline $\mathrm{C} 18: 3(\gamma-\mathrm{LA})$ & $0.00 \pm 0.00$ & $0.00 \pm 0.00$ & $0.00 \pm 0.00$ & $0.00 \pm 0.77$ & $0.00 \pm 0.72$ & $0.00 \pm 0.88$ \\
\hline$\sum$ PUFA & 0.41 & 0.14 & 0.38 & 0.09 & 0.08 & 0.11 \\
\hline C20:4 $\omega-6$ (ARA) & $0.00 \pm 0.00$ & $0.00 \pm 0.00$ & $0.00 \pm 0.00$ & $0.24 \pm 0.00$ & $0.21 \pm 0.00$ & $0.28 \pm 0.00$ \\
\hline C20:5 $\omega-3$ (EPA) & $2.66 \pm 2.35$ & $0.40 \pm 1.11$ & $6.00 \pm 0.31$ & $4.08 \pm 2.01$ & $3.55 \pm 0.89$ & $4.73 \pm 2.33$ \\
\hline $\mathrm{C} 22: 6 \omega-3$ (DHA) & $5.16 \pm 4.54$ & $0.76 \pm 2.42$ & $10.81 \pm 0.55$ & $0.00 \pm 2.27$ & $0.00 \pm 1.96$ & $0.00 \pm 9.07$ \\
\hline$\sum$ HUFA & 11.70 & 1.16 & 16.81 & 4.32 & 3.76 & 5.01 \\
\hline$\sum$ FA & 39.59 & 4.01 & 43.79 & 30.21 & 26.33 & 35.01 \\
\hline$\omega-6 / \omega-3$ & 0.04 & 0.12 & 0.02 & 0.08 & 0.08 & 0.08 \\
\hline $\mathbf{N}$ & 9 & 9 & 8 & 8 & 8 & 8 \\
\hline
\end{tabular}

Significant differences between the species studied regarding the FA content of the four FA classes analyzed can be observed in Figure 1. Species are considerably different from each other concerning different fatty acid classes. Gracilaria gracilis stands out due to its high content in SFA, while $C$. jubata stands out due to its higher content in HUFA compared to the remaining FA classes; the three forms of G. turuturu present an interesting profile, with both SFA and HUFA standing out. Apart from $U$. pinnatifida, PUFA was the FA class in lower concentration compared to the remaining studied species. The n-MDS conducted for the algae species studied is presented in Figure 2.

The results show five different groups: group A, composed of G. turuturu replicates, including the stages of fructified gametophyte, non-fructified gametophyte, and tetrasporophyte; group B, including $C$. teedei in the form of female gametophyte replicates; group $C$, comprising G. gracilis replicates; group D, which includes $C$. teedei male gametophyte and tetrasporophyte, C. jubata replicates, C. peregrina and A. armata; and group E, composed of S. muticum and $U$. pinnatifida specimens. Significant differences were found between every group. The fatty acids C16:0, $\alpha$ and $\gamma$-LA, EPA, and DHA were the most determinant for differentiating the groups. Palmitic acid contributed the most to the dissimilarity between groups D and B (23.20\%), C and B (35.68\%), B and A (30.90\%), and C and A, although in this case, $\mathrm{C} 16: 0, \mathrm{C} 18: 1$, and $\mathrm{C} 15: 1$ were equivalently important to differentiate the groups (contributing, respectively, to $24.91 \%, 24.12 \%$, and $22.35 \%$ of the dissimilarity between the groups). DHA, $\gamma$-LA and $\alpha$-LA were, in this order, determining to differentiate groups E and C (contributing to $17.73 \%, 16.50 \%$, and $16.50 \%$, respectively) and groups E and A (contributing to $14.43 \%, 13.58 \%$, and $12.64 \%$, respectively). Regarding groups D and A, DHA contributed to $25.31 \%$ of the dissimilarity between groups, while contributing to $33.75 \%$ to the dissimilarities between groups D and C, as G. gracilis does not possess DHA in its profile, while the species of group D do. In groups D and E, $\gamma$-LA and $\alpha$-LA contributed similarly to the similarity, contributing together to $37.05 \%$ of the dissimilarity. Groups $\mathrm{E}$ and B were differentiated by the contents of EPA, C16:0 and $\gamma$-LA and $\alpha$-LA (contributing to $14.84 \%, 13.12 \%, 12.96 \%$, and $12.80 \%$, respectively). The average dissimilarities between groups, as well as the main three FA contributing for the dissimilarities between groups, are presented in Table 5. 
Table 5. SIMPER results regarding dissimilarities (diss.) between the groups identified (A-G. turuturu fructified gametophyte, non-fructified gametophyte, and tetrasporophyte; B-C. teedei female gametophyte; C-G. gracilis; D-C. teedei male gametophyte and tetrasporophyte, $C$. jubata, C. peregrina, and A. armata; E-S. muticum and U. pinnatifida), presenting the average dissimilarity (Av. diss.) between groups, the three FA that contribute the most for dissimilarities between groups, including the percentage of contribution to that dissimilarity and the cumulative contribution of those three FA for the total dissimilarity between groups, in percentage.

\begin{tabular}{|c|c|c|c|c|}
\hline Groups & $\begin{array}{l}\text { Av. diss. between } \\
\text { Groups }\end{array}$ & Main FA & $\begin{array}{l}\% \text { Contribution } \\
\text { to diss. }\end{array}$ & $\begin{array}{c}\% \text { Cumulative } \\
\text { Contribution to diss. }\end{array}$ \\
\hline \multirow{3}{*}{$\mathrm{D}, \mathrm{E}$} & \multirow{3}{*}{37.98} & EPA & 19.96 & \multirow{3}{*}{49.75} \\
\hline & & $\gamma$-LA & 15.85 & \\
\hline & & $\alpha-\mathrm{LA}$ & 13.94 & \\
\hline \multirow{3}{*}{$D, C$} & \multirow{3}{*}{38.58} & C16:0 & 47.58 & \multirow{3}{*}{81.64} \\
\hline & & DHA & 24.89 & \\
\hline & & C18:1 & 9.17 & \\
\hline \multirow{3}{*}{$\mathrm{E}, \mathrm{C}$} & \multirow{3}{*}{50.01} & C16:0 & 36.05 & \multirow{3}{*}{59.46} \\
\hline & & DHA & 11.74 & \\
\hline & & EPA & 11.67 & \\
\hline \multirow{3}{*}{$\mathrm{D}, \mathrm{B}$} & \multirow{3}{*}{85.65} & C16:0 & 39.13 & \multirow{3}{*}{72.93} \\
\hline & & DHA & 21.86 & \\
\hline & & C18:1 & 11.94 & \\
\hline \multirow{3}{*}{ E,B } & \multirow{3}{*}{89.62} & C16:0 & 21.14 & \multirow{3}{*}{52.14} \\
\hline & & EPA & 19.32 & \\
\hline & & $\gamma$-LA & 11.67 & \\
\hline \multirow{3}{*}{ C, B } & \multirow{3}{*}{90.88} & C16:0 & 63.01 & \multirow{3}{*}{86.06} \\
\hline & & C18:1 & 14.24 & \\
\hline & & C15:1 & 8.81 & \\
\hline \multirow{3}{*}{$\mathrm{D}, \mathrm{A}$} & \multirow{3}{*}{45.84} & DHA & 29.60 & \multirow{3}{*}{58.05} \\
\hline & & C16:0 & 15.38 & \\
\hline & & EPA & 13.08 & \\
\hline \multirow{3}{*}{ E,A } & \multirow{3}{*}{53.45} & EPA & 15.48 & \multirow{3}{*}{44.40} \\
\hline & & DHA & 14.56 & \\
\hline & & $\gamma$-LA & 14.35 & \\
\hline \multirow{3}{*}{$\mathrm{C}, \mathrm{A}$} & \multirow{3}{*}{51.04} & C16:0 & 54.82 & \multirow{3}{*}{79.58} \\
\hline & & C18:1 & 14.44 & \\
\hline & & EPA & 10.33 & \\
\hline \multirow{3}{*}{ B,A } & \multirow{3}{*}{82.71} & C16:0 & 45.61 & \multirow{3}{*}{75.62} \\
\hline & & EPA & 21.40 & \\
\hline & & ARA & 8.61 & \\
\hline
\end{tabular}




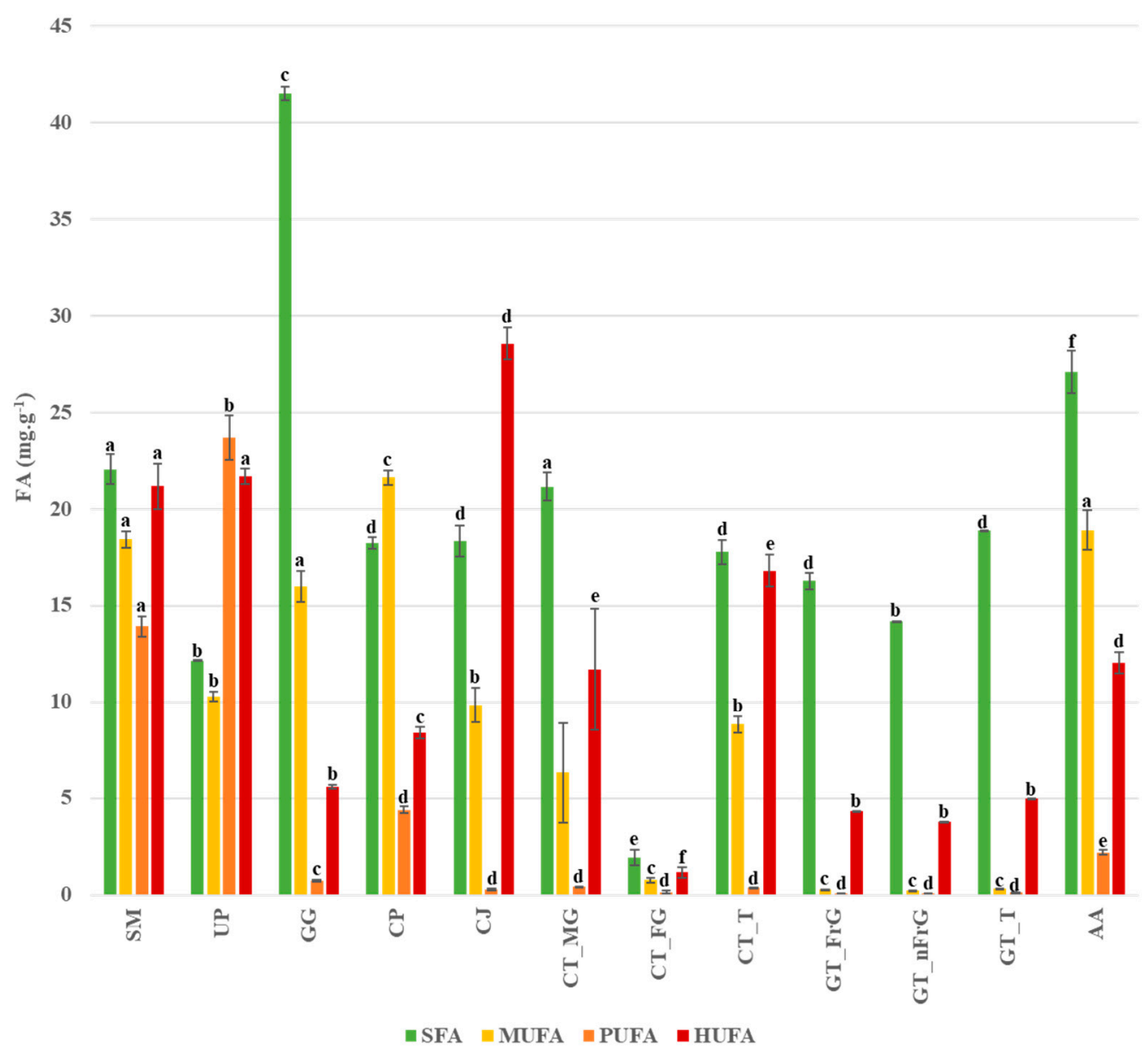

Figure 1. Concentration of the four fatty acids groups (SFA, MUFA, PUFA, HUFA) present in the specimens of the species studied: SM-Sargassum muticum, UP-Undaria pinnatifida, GG-Gracilaria gracilis, CP-Colpomenia peregrina, CJ-Calliblepharis jubata, CT_MG-Chondracanthus teedei var. lusitanicus (male gametophyte), CT_GF-Chondracanthus teedei var. lusitanicus (female gametophyte), CT_T-Chondracanthus teedei var. lusitanicus (tetrasporophyte), GT_FG-Grateloupia turuturu (fructified gametophyte), GT_nFG_Grateloupia turuturu (non-fructified gametophyte), GT_T-Grateloupia turuturu (tetrasporophyte), AA-Asparagopsis armata. Statistically significant differences in the same fatty acid content among the species are expressed by letters above the bars.

Considering each species individually, it is worth noticing the contribution of C16:0 to the total FA content of G. gracilis, C. teedei var. lusitanicus (male gametophyte), and A. armata, corresponds to over $60 \%, 50 \%$, and $43 \%$ of the algae's total FA content, respectively. It is also interesting to note the content of DHA of $C$. jubata, corresponding to circa $50 \%$ of the algae's total FA content. Overall, C16:0 was the most abundant SFA of the studied species, EPA was present in all specimens analyzed, and DHA was the most abundant HUFA, whenever present. 


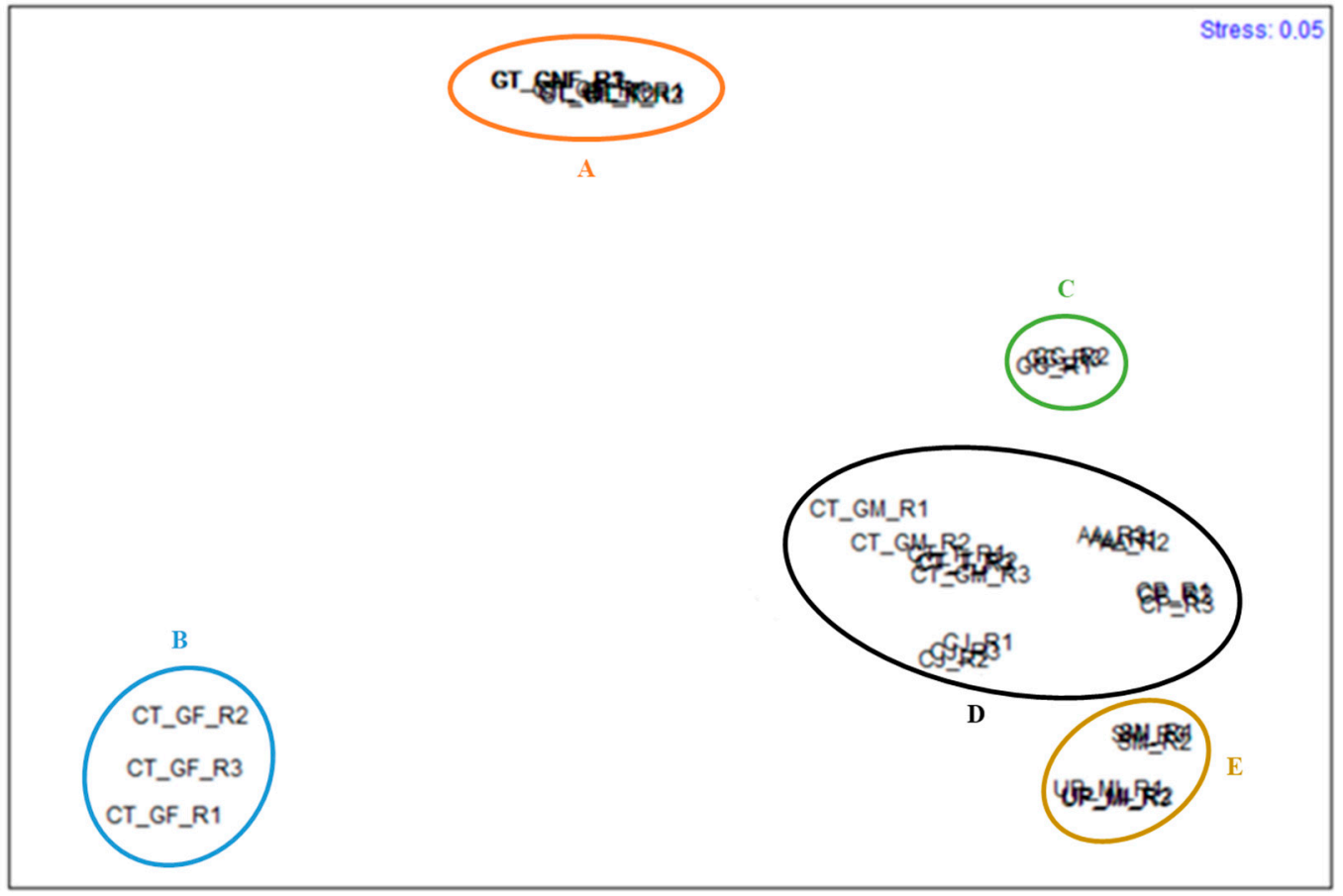

Figure 2. n-MDS of the species studied, regarding the fatty acid profile and content: Sargassum muticum (SM_R1, SM_R2,SM_R3), Undaria pinnatifida (UP_MI_R1, UP_MI_R2, UP_MI_R3), Gracilaria gracilis (GG_R1, GG_R2, GG_R3), Colpomenia peregrina (CP_R1, CP_R2, CP_R3), Calliblepharis jubata (CJ_R1, CJ_R2, CJ_R3), Chondracanthus teedei (male gametophyte) (CT_MG_R1, CT_MG_R2, CT_MG_R3), Chondracanthus teedei (female gametophyte) (CT_GF_R1, CT_GF_R2,CT_GF_R3), Chondracanthus teedei (tetrasporophyte) (CT_T_R1, CT_T_R2, CT_T_R3), Grateloupia turuturu (fructified gametophyte) (GT_FrG_R1, GT_FrG_R2, GT_FrG_R3), Grateloupia turuturu (non-fructified gametophyte) (GT_nFrG_R1, GT_nFrG_R2,GT_nFrG_R3), Grateloupia turuturu (tetrasporophyte) (GT_T_R1, GT_T_R2,GT_T_R3), Asparagopsis armata (AA_R1, AA_R2, AA_R3). Five groups have been identified composed by the following samples: A - GT_FrG_R1, GT_FrG_R2, GT_FrG_R3,GT_nFrG_R1, GT_nFrG_R2, GT_nFrG_R3, GT_T_R1,GT_T_R2,GT_T_R3); B - CT_GF_R1,CT_GF_R2,CT_GF_R3; C-GG_R1, GG_R2,GG_R3; D-CT_MG_R1, CT_MG_R2, CT_MG_R3, CT_T_R1,CT_T_R2,CT_T_R3, CJ_R1, CJ_R2, CJ_R3, CP_R1, CP_R2, CP_R3, AA_R1, AA_R2, AA_R3; and E-SM_R1, SM_R2, SM_R3,UP_MI_R1, UP_MI_R2,UP_MI_R3.

\section{Discussion}

Red and brown seaweeds are particularly well-known sources of $\omega-3$ PUFA and HUFA [35]. Nevertheless, the lipidic profile is specific and a characteristic signature of each seaweed, being dependent on the factors the organism is subjected to [36-38], and thus potentially indicative of the conditions that algae has been subjected to. In this context, the geolocation and the exposure to different abiotic (i.e., temperature, salinity, $\mathrm{pH}$, wave exposure, light, nutrient availability) and biotic factors (i.e., herbivory) can lead to different biochemical profiles in the same species, being changes in the FA profile that are particularly noticeable and interesting from a human nutritional perspective [36,39-41].

The brown seaweed S. muticum (Figure 3a) is native to Japan and considered an invasive species in Atlantic waters [42-44]. Despite the nutritional potential of this seaweed having already been highlighted by several authors $[17,19,45]$, currently, there is no economical exploitation of this species by the food industry [46]. Even though the lipid fraction represents a low part of seaweeds' constitution, they contain essential fatty acids pivotal for human health [18]. Similarly to the studies conducted by Santos et al. (2020) and Debbarma et al. (2016) [47,48], which revealed that palmitic acid (C16:0) was the most abundant FA present in S. muticum, representing, respectively, $24.18 \%$ and $43.10 \%$ of the algae's total fatty acid fraction, the present study too presents palmitic acid as the 
most abundant FA. However, biomass collected in Aguda beach (Porto), during the spring showed a more diverse lipid profile, exhibiting PUFA (such as, C16:2, 20:2 and 20:3), HUFA (like 18:4 $\omega-3$ ), MUFA (likewise, C20:1 and C22:1), and SFA (namely, C14:0, C15:0, C20:0 and C22:0) [47] that were not detected in our study with S. muticum harvested in Buarcos Bay (Figueira da Foz) during the autumn. Previous research showed that in fact, S. muticum FA content varies throughout seasons, reaching its maximum yield during the spring and its minimum in the winter [19]. Moreover, it is noted that S. muticum content of PUFA reported by Santos et al. (2020) is significantly higher than in this study [47]. A water temperature gradient is observed throughout the Portuguese coast, being registered higher water temperatures in the South of the country and lower in the North. Thus, the FA profile of a same algae species also differs according to the sea water temperature, depending on the zone it is harvested from. For instance, it has been reported that seaweeds collected in zones with colder waters have a higher PUFA content than those of the same species from warmer waters [19], further supporting this discrepancy between a same species harvested from different sampling sites.

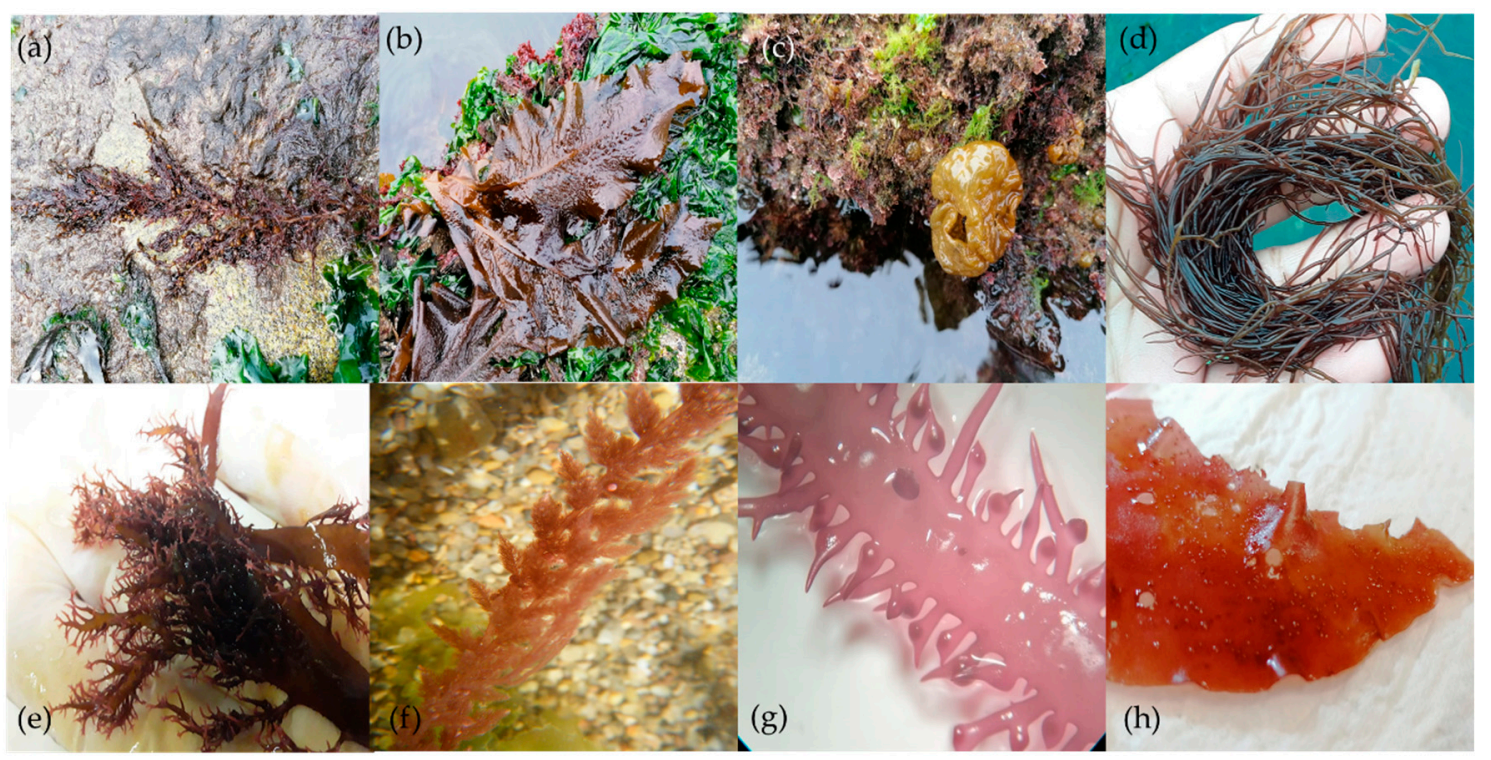

Figure 3. Brown seaweeds (a) Sargassum muticum, (b) Undaria pinnatifida, and (c) Colpomenia peregrina; red seaweeds (d) Gracilaria gracilis, (e) Calliblepharis jubata, (f) Asparagopsis armata, (g) Chondracanthus teedei var. lusitanicus (female gametophyte), and (h) Grateloupia turuturu (fructified gametophyte).

For the food industry, the brown seaweed $U$. pinnatifida or wakame (Figure $3 b$ ) is one of the most representative sea vegetables, particularly in Asiatic countries (its native area), where their aquaculture production reaches its greatest expression, contributing significantly to seaweeds' global production and trade [49]. This species holds a high economic value due to its rich nutritional value and human health promoting properties, which stirred the attention of the worldwide food market [50]. However, the cultivation of this species in European waters is not legally allowed, due to their non-indigenous character and invasive behavior [51]. As a result, this invasive species cannot be grown in non-native ecosystems; still, it can be harvested from coastal areas and directly or indirectly introduced into the daily human diet. Due to the widespread presence of this brown seaweed along the European shoreline, it represents a valuable feedstock for the food industry [52]. Furthermore, U. pinnatifida contains essential FA for human health promotion, such as EPA, ARA, and DHA [53]. Nevertheless, there are several parameters that can affect this seaweed FA composition and content. For instance, U. pinnatifida harvested from the Brittany coast (France) exhibited a much lower amount of total FA $\left(16.6 \mathrm{mg} \cdot \mathrm{g}^{-1}\right)$ and an overall different lipidic profile compared to the specimens analyzed in the present study [54]. Moreover, in the southwest coast of Golfo Nuevo (Argentina), 
U. pinnatifida exhibited not only lower values of total FA, SFA, MUFA, and PUFA (18.1, 2, 1 , and $15 \mathrm{mg} \cdot \mathrm{g}^{-1}$, respectively), but also a different fatty acid profile. For instance, this species presented SFA, such as C14:0, C15:0, C20:0, and C22:0; PUFA, namely C20:3; and HUFA, such as C18:4 and C22:5 ( $\omega-3)$ [53]. Several studies found that palmitic acid (C16:0) was the most abundant $U$. pinnatifida FA [53,55]; however, in the present study it was found that eicosapentaenoic acid $\left(13.15 \mathrm{mg} \cdot \mathrm{g}^{-1}\right)$ was the most representative, which could be due to different environmental conditions that this algae may be exposed to. Despite all the aforementioned factors that affect the FA concentration and constitution, its profile can also differ according to the part of the seaweed analyzed. For instance, researchers found that the FA profile varies if the analysis is performed on the sporophyll, the frond, or in the midrib of $U$. pinnatifida [53].

The brown seaweed C. peregrina (Figure 3c) is a cosmopolitan species that is considered non-indigenous in the Atlantic Ocean [56-58]. Despite its nutritional value, this species is still an unexploited resource for the food industry $[15,59]$. Yet, this brown seaweed's FA profile and relevance for human nutrition has already been studied. For instance, C. peregrina harvested in the Atlantic Ocean (England) showed a diverse lipidic profile, exhibiting the same amount $\left(16.7 \mathrm{mg} \cdot \mathrm{g}^{-1}\right)$ of the SFAs C14:0, C16:0, C18:0, and C18:1, and the HUFA C20:4 and C20:5 [59], while in our study, C. peregrina not only showed a different FA profile, but also presented different concentrations of each FA.

The species G. gracilis (Rhodophyta) (Figure 3d) is among the seaweeds with increasing demand and therefore economic relevance [49]. As a result, increasing research has been conducted to enhance cultivation and evaluate the nutraceutical relevance of this seaweed [60-62]. Previous research showed that G. gracilis biochemical composition is dependent on the depth it grows. For instance, the total lipid content was higher in the seaweed cultured at a depth of $2.5 \mathrm{~m}$ than the seaweed cultivated at $0.5 \mathrm{~m}$ [63]. Nevertheless, researchers studied G. gracilis FA profile variation during the harvesting season and found that the total content and the lipid (and fatty acid in particular) composition of this seaweed collected at the Lesina lagoon (Italy) is higher and more diverse in the spring and lower and less diverse in the autumn [60]. Despite some differences in the FA profile, our results are in line with Capillo et al. (2018) [64], where the most abundant FA registered were palmitic acid (C16:0) and oleic acid (C18:1). In contrast, these researchers found a high concentration of arachidonic acid (C20:4 $\omega-6)$ [64], whereas the mentioned FA was not found in the study presented here.

The native red seaweed C. jubata (Figure 3e) is a carrageenan producer, being this molecule pivotal for the food industry, with widespread applications. Yet, C. jubata is an unexploited resource as a food product itself or its molecules (i.e., carrageenan) $[65,66]$. Still, researchers highlight its nutritional potential, particularly as an essential FA source, being the most representative of the palmitic acid (C16:0) and the eicosapentaenoic acid (C20:5 $\omega$-3) from C. jubata harvested in France [67]. Concurrently, in our study, C. jubata revealed a higher concentration of C22:6 (DHA). Thus, researchers showed that the FA profile of the red seaweed C. jubata varies between geographical locations, but also among wild species, laboratory, and inshore cultivated species. For instance, the inshore cultivated C. jubata presented an increasingly diverse fatty acid profile, exhibiting a high concentration of total PUFA, in comparison with wild specimens [66]. The results of the total FA, SFA, MUFA, PUFA, and HUFA of $C$. jubata wild specimens collected in the spring at Buarcos Bay (Figueira da Foz) are in line with our results, exhibiting a similar FA composition, but highlighting the presence of the SFA tetradecanoic acid (C14:0) [66], which was not identified in the specimens studied.

In 1920, the red seaweed A. armata (Figure 3f), which is native to Australia, was deliberately introduced into Europe due to the high food demand [68-70]. In the past, this species has been incorporated in the human daily diet due to its valuable nutritional composition [71]. Among several micronutrients and trace elements that are essential for the proper functioning of the human organism, this non-native seaweed presents nutraceutical potential as a food supplement [71,72]. For instance, the red seaweed $A$. armata 
harvested in the Algarve coast (South of Portugal) during the spring showed an overall similar sum of SFA, MUFA, and PUFA, presenting a higher concentration of SFA and a lower PUFA amount. Nevertheless, the FA composition showed some differences, namely through the presence of the SFAs C12:0, C14:0, C15:0, and C18:0 [36].

The red seaweed C. teedei var. lusitanicus (Figure $3 \mathrm{~g}$ ) is an edible seaweed with nutraceutical potential [24,73-75]; however, to the best of our knowledge, there is no previous literature reporting this species' FA characterization, the present study being the first to present such findings.

Despite reports that G. turuturu (Figure 3h) is consumed directly in Asian countries, the full nutraceutical potential of this non-native seaweed has yet to be discovered in Europe [76]. Some scientists, on the other hand, are curious about their chemical structure and bioactivities [72,77-80]. A study conducted with G. turuturu harvested in the Nord-East Atlantic coast of France revealed that the FA composition and concentration of each FA varies according to the season in which the seaweed is collected $[78,79,81]$. In comparison to our study, despite the FA profile differences, the most abundant MUFA and HUFA synthesized in the winter was also $C 16: 0$ and C20:5 $\omega-3$, respectively $[78,79,81]$. Moreover, the storage methods can also influence G. turuturu compounds' concentration and characterization [80].

Compared to terrestrial plants, seaweeds present a wider variety of metabolites with important biological properties, as well as higher abundances of highly unsaturated fatty acids, namely the $\omega-3$ EPA and DHA and the $\omega-6$ ARA, being particularly important for the introduction of such macronutrients in food webs [82]. Thus, seaweeds present a high potential not only as a direct food product, but also for technological applications that can use their biological compounds to produce functional foods $[19,82]$.

Lipids are a varied group with structural, functional, storage, signaling, and transcription factor activities and characteristics, needed for numerous metabolic processes. Omega-3 fatty acids, of which marine algae are important sources, are essential for animal nutrition, as most animals, including humans, are not able to produce them, or, at least, not at the needed rate to meet the metabolic demands. PUFA and HUFA have particular important functions in human metabolism, being crucial for early human developmental stages and contributing to the prevention of cardiovascular diseases as well as obesity and linked morbidities by enhancing lipid and glucose metabolism, and have a protective effect against cancers and inflammatory processes. It is, therefore, important to consume an appropriate amount of such fatty acids, and maintain a balanced diet when it comes to fatty acid intake $[60,83,84]$. For years, the main source of dietary PUFA and HUFA, especially omega-3 fatty acids, has been marine fish-derived products, but the advances in knowledge concerning the beneficial effects of these compounds to human health have increased the demand for such products, leading to the search for alternative sources, including seaweeds [85-87]. Optimum values for omega-3 fatty acids' daily consumption have been discussed by many health organizations worldwide which, although differing somewhat in recommended quantities, overall propose a combined consumption of EPA and DHA of $250-500 \mathrm{mg}$ per day for healthy adults [88,89]. When analyzing the results obtained in the present study, we confirm that the contribution of each algae to the daily recommended intake values varied depending on the species. The intake of $250 \mathrm{mg}$ of EPA+DHA may be met by ingesting only around $68 \mathrm{~g}$ of fresh Calliblepharis jubata, or $90 \mathrm{~g}$ of Undaria pinnatifida, for example, while the same omega-3 intake regarding Grateloupia turuturu would take ingesting between 415 to $550 \mathrm{~g}$ of fresh algae, depending on its life stage.

The importance of the $\omega-6 / \omega-3$ FA ratio in human diets has gained relevance over the past few years, given the association of an imbalance of this ratio with the appearance of numerous diseases of cardiovascular, inflammatory, autoimmune, or carcinogenic natures [84,90,91], as well as obesity and associated morbidities [90]. A $\omega-6 / \omega-3$ fatty acid ratio of 1 is deemed as optimal for human diets, as to prevent the appearance of diseases, but imbalances of this ratio are quite common in diets across the world. The World Health Organization (WHO) recommends a $\omega-6 / \omega-3$ ratio lower than 10 in diets 
to prevent deleterious health effects [92]. The most imbalanced diets reported are among the populations of Europe and the United States of America, marked by a high dietary intake of $\omega-6$ fatty acids from a diet rich in vegetable oils, and have been reported to go up 20-50, being less elevated in countries as Japan, where the ratio lies around 12 [33,59]. Nonetheless, these high ratios across the world have some exceptions, as is the case of Greenland Eskimos, whose diets present a ratio of $\sim 1$, due to the high consumption of fish that constitute a valuable source of $\omega-3$ fatty acids [85] and contribute to balancing the ratio $[93,94]$. The fatty acid content of seaweeds is somewhat variable depending on the factors the organisms are subjected to, with the differences particularly noticeable among seasons, as discussed above. In general, algae have been reported to have a $\omega-6 / \omega-3$, ratio always below the ratio recommended by the $\mathrm{WHO}$, which is 10 , attaining minimum ratio values in springtime. The studied algae are concordant with these reports: for instance, Sargassum species have been reported elsewhere presenting ratios between 0.55 [95] and 3.37 [19], the latter referring to S. muticum, with minimum values during spring months. The species S. muticum studied in the present work showed lower values (of 0.15), representing an even better value, probably due to the environmental factors the algae are subjected to in the Portuguese coast, considering that this is a non-indigenous species. Red seaweeds are also reported to rarely surpass the ratio limit of 10 - this was reported in Francavilla et al. (2013) [60] referring to Gracilaria, where a ratio above 10 was found in specimens collected in January that presented very high amounts of ARA, but the ratio dropped to below this limit in spring, when the maximum content of FA was also observed.

All algae species addressed in the present work present a $\omega-6 / \omega-3$ ratio far below 1 , meaning that their introduction in diets may be beneficial from a nutraceutical perspective, as they provide essential fatty acids needed for numerous metabolic processes while contributing to the lowering of the $\omega-6 / \omega-3$ ratio of the consumers' diet, contributing to the prevention of the diseases already mentioned.

In terms of the most suitable algae amongst those studied that would be suitable for food industry applications, it was interesting to note the cumulative potential benefits that would come from the overall low $\omega-6 / \omega-3$ ratios in combination with low SFA contents (higher PUFA+HUFA/SFA ratios). Although it is known that an exceedingly high PUFA/SFA ratio in diets may be also deleterious to human health, as PUFA are more susceptible to oxidative stress and peroxidation, which may contribute to ageing of tissues and associated morbidities [94-96], SFA are present in most foodstuffs of Western diets, and a higher PUFA/SFA ratio in the algae studied could also contribute to the overall FA balance of diets. Thus, we consider that $C$. jubata and $U$. pinnatifida could be the species among the studied that gather the mentioned characteristics, followed by S. muticum and C. teedei tetrasporophyte, the latter two presenting higher contents of SFA but still attaining high contents of PUFA+HUFA. G. gracilis, C. teedei var. lusitanicus (female gametophyte), and G. turuturu of all three stages seem to be the ones that would contribute the least to the mentioned objectives, by their FA profiles. It would also be interesting to further explore the nutritional and nutraceutical potential of $A$. armata, as it possesses an interesting FA profile, with a rather high content in the omega- 3 fatty acids EPA and DHA. In addition, other studies have reported that some of the algae addressed in this study possess other high-quality components, such as polysaccharides, micronutrients, trace elements and vitamins $[97,98]$. It would, then, be interesting to undergo future studies with the studied algae to determine the potential effects that their other components may have on human health, both from positive and negative perspectives, to provide more complete information and the range of possibilities concerning the overall potential of algae as alternative sources that may be exploited by the food and nutraceutical industries.

\section{Conclusions}

Both red and brown seaweeds are a reservoir of bioactive compounds with several biotechnological applications. Among algal compounds, PUFA are essential components of human nutrition and are considered to have a variety of health benefits. Dietary PUFA 
consumption, which contains both $\omega-3$ and $\omega-6$ FA, has been shown to affect inflammatory processes and other cell functions, with the understanding of the $\omega-6 / \omega-3$ ratio proven to be essential to predict possible health implications of the consumption of the algae, or of foods in general.

Calliblepharis jubata and Undaria pinnatifida were the algae among those harvested proving to be the most suitable for food industry applicability in terms of the potential nutraceutical benefits they present. Both algae present high contents in polyunsaturated and highly unsaturated fatty acids, with $\omega-3$ FA being the most prominent, as may also be confirmed given their low $\omega-6 / \omega-3$ ratios (of 0.01 and 0.09 , respectively). Although all studied algae present very low $\omega-6 / \omega-3$ ratios, which may contribute to the prevention of diseases, $C$. jubata and $U$. pinnatifida combine that characteristic with SFA contents lower that PUFA+HUFA contents, which does not happen in the remaining species.

Regardless of the nutraceutical potential of seaweeds, it is crucial to ensure their longterm development through cultivation techniques that ensure the final product's safety and quality. Furthermore, seaweed processing and transformation must be considered in order to maintain the FA profile and concentration, as well as the stability of these important components. From an industrial and commercial standpoint, it is essential to ensure that the nutraceutical potential is given from the cultivation/harvesting to the final product.

Author Contributions: Conceptualization, C.P.R., D.P., J.C., J.C.M., L.P., A.M.M.G.; methodology, C.P.R., D.P., J.C., L.P., A.M.M.G.; investigation, C.P.R., D.P., J.C.; data curation, C.P.R. and A.M.M.G.; writing—original draft preparation, C.P.R., D.P., J.C.; writing—review and editing, C.P.R., D.P., J.C., J.C.M., L.P., A.M.M.G.; supervision, J.C.M., L.P., A.M.M.G. All authors have read and agreed to the published version of the manuscript.

Funding: This work is financed by national funds through FCT-Foundation for Science and Technology, I.P., within the scope of the projects UIDB/04292/2020 granted to MARE-Marine and Environmental Sciences Centre and UIDP/50017/2020+UIDB/50017/2020 (by FCT/MTCES) granted to CESAM-Centre for Environmental and Marine Studies. This research was co-financed by the project MENU_Marine Macroalgae: Alternative recipes for a daily nutritional diet (FA_05_2017_011), funded by the Blue Fund under Public Notice No. 5-Blue Biotechnology. Diana Pacheco thanks to PTDC /BIA-CBI/31144/2017-POCI-01 project-0145-FEDER-031144-MARINE INVADERS, cofinanced by the ERDF through POCI (Operational Program Competitiveness and Internationalization) and by the Foundation for Science and Technology (FCT, IP). João Cotas thanks the European Regional Development Fund through the Interreg Atlantic Area Program, under the project NASPA (EAPA_451/2016). Ana M. M. Gonçalves acknowledges the University of Coimbra for the contract IT057-18-7253.

Institutional Review Board Statement: Not applicable.

Informed Consent Statement: Not applicable.

Data Availability Statement: The data reported in the present study is compared and discussed in relation to other published works on the subject, as identified and cited throughout the manuscript. There was no resort to publicly available datasets.

Conflicts of Interest: The authors declare no conflict of interest.

\section{References}

1. Gupta, U.C.; Gupta, S.C. Sources and Deficiency Diseases of Mineral Nutrients in Human Health and Nutrition: A Review. Pedosphere 2020, 24, 13-38. [CrossRef]

2. Simopoulos, A.P. An increase in the Omega-6/Omega-3 fatty acid ratio increases the risk for obesity. Nutrients 2016, 8. [CrossRef]

3. Miles, E.A.; Calder, P.C. Modulation of immune function by dietary fatty acids. Proc. Nutr. Soc. 1998, 57, 277-292. [CrossRef] [PubMed]

4. Riccardi, G.; Giacco, R.; Rivellese, A. Dietary fat, insulin sensitivity and the metabolic syndrome. Clin. Nutr. 2004, 23, 447-456. [CrossRef] [PubMed]

5. Brown, E.M.; Allsopp, P.J.; Magee, P.J.; Gill, C.I.; Nitecki, S.; Strain, C.R.; McSorley, E.M. Seaweed and human health. Nutr. Rev. 2014, 72, 205-216. [CrossRef] [PubMed]

6. Leandro, A.; Pacheco, D.; Cotas, J.; Marques, J.C.; Pereira, L.; Gonçalves, A.M.M.M. Seaweed's Bioactive Candidate Compounds to Food Industry and Global Food Security. Life 2020, 10, 140. [CrossRef] 
7. Duarte, C.; Boccardi, V.; Amaro Andrade, P.; Souza Lopes, A.C.; Jacques, P.F. Dairy versus other saturated fats source and cardiometabolic risk markers: Systematic review of randomized controlled trials. Crit. Rev. Food Sci. Nutr. 2021, 61, 450-461. [CrossRef]

8. Godfray, H.C.J.; Beddington, J.R.; Crute, I.R.; Haddad, L.; Lawrence, D.; Muir, J.F.; Pretty, J.; Robinson, S.; Thomas, S.M.; Toulmin, C. Food Security: The Challenge of Feeding 9 Billion People. Science 2010, 327, 812-818. [CrossRef]

9. Michalak, I.; Chojnacka, K. Algae as production systems of bioactive compounds. Eng. Life Sci. 2015, 15, 160-176. [CrossRef]

10. Galloway, A.W.E.; Britton-Simmons, K.H.; Duggins, D.O.; Gabrielson, P.W.; Brett, M.T. Fatty acid signatures differentiate marine macrophytes at ordinal and family ranks. J. Phycol. 2012, 48, 956-965. [CrossRef]

11. Ibañez, E.; Herrero, M.; Mendiola, J.A.; Castro-Puyana, M. Extraction and Characterization of Bioactive Compounds with Health Benefits from Marine Resources: Macro and Micro Algae, Cyanobacteria, and Invertebrates. In Marine Bioactive Compounds; Springer: Boston, MA, USA, 2012; Volume 9781461412, pp. 55-98.

12. Tanna, B.; Mishra, A. Metabolites Unravel Nutraceutical Potential of Edible Seaweeds: An Emerging Source of Functional Food. Compr. Rev. Food Sci. Food Saf. 2018, 17, 1613-1624. [CrossRef] [PubMed]

13. European Union Convention on the Conservation of European Wildlife and Natural Habitats. Environ. Conserv. 1981, 8, 206. [CrossRef]

14. van Kleunen, M.; Weber, E.; Fischer, M. A meta-analysis of trait differences between invasive and non-invasive plant species. Ecol. Lett. 2010, 13, 235-245. [CrossRef] [PubMed]

15. Pacheco, D.; Araújo, G.S.; Cotas, J.; Gaspar, R.; Neto, J.M.; Pereira, L. Invasive Seaweeds in the Iberian Peninsula: A Contribution for Food Supply. Mar. Drugs 2020, 18, 560. [CrossRef]

16. Salvaterra, T.; Green, D.S.; Crowe, T.P.; O'Gorman, E.J. Impacts of the invasive alga Sargassum muticum on ecosystem functioning and food web structure. Biol. Invasions 2013, 15, 2563-2576. [CrossRef]

17. Milledge, J.J.; Nielsen, B.V.; Bailey, D. High-value products from macroalgae: The potential uses of the invasive brown seaweed, Sargassum muticum. Rev. Environ. Sci. Biotechnol. 2016, 15. [CrossRef]

18. Milledge, J.; Harvey, P. Golden Tides: Problem or Golden Opportunity? The Valorisation of Sargassum from Beach Inundations. J. Mar. Sci. Eng. 2016, 4, 60. [CrossRef]

19. Balboa, E.M.; Gallego-Fábrega, C.; Moure, A.; Domínguez, H. Study of the seasonal variation on proximate composition of oven-dried Sargassum muticum biomass collected in Vigo Ria, Spain. J. Appl. Phycol. 2016, 28, 1943-1953. [CrossRef]

20. Cotas, J.; Leandro, A.; Pacheco, D.; Gonçalves, A.M.M.M.; Pereira, L. A comprehensive review of the nutraceutical and therapeutic applications of red seaweeds (Rhodophyta). Life 2020, 10, 19. [CrossRef] [PubMed]

21. García-Poza, S.; Leandro, A.; Cotas, C.; Cotas, J.; Marques, J.C.; Pereira, L.; Gonçalves, A.M.M. The Evolution Road of Seaweed Aquaculture: Cultivation Technologies and the Industry 4.0. Int. J. Environ. Res. Public Health 2020, 17, 6528. [CrossRef]

22. García-Jiménez, P.; Robaina, R.R. On reproduction in red algae: Further research needed at the molecular level. Front. Plant Sci. 2015, 6. [CrossRef]

23. Katsanevakis, S.; Acar, Ü.; Ammar, I.; Balci, B.A.; Bekas, P.; Belmonte, M.; Chintiroglou, C.C.; Consoli, P.; Dimiza, M.; Fryganiotis, K.; et al. New Mediterranean Biodiversity Records (October, 2014). Mediterr. Mar. Sci. 2014, 15, 675. [CrossRef]

24. Pereira, L.; Silva, P. A concise review of the red macroalgae Chondracanthus teedei (Mertens ex Roth) Kützing and Chondracanthus teedei var. lusitanicus (J.E. De Mesquita Rodrigues) Bárbara \& Cremades. J. Appl. Phycol. 2021, 33, 111-131. [CrossRef]

25. Cardoso, I.; Cotas, J.; Rodrigues, A.; Ferreira, D.; Osório, N.; Pereira, L. Extraction and Analysis of Compounds with Antibacterial Potential from the Red Alga Grateloupia turuturu. J. Mar. Sci. Eng. 2019, 7, 220. [CrossRef]

26. Pereira, L. Population Studies and Carrageenan Properties in Eight Gigartinales (Rhodophyta) from Western Coast of Portugal. Sci. World J. 2013, 2013, 1-11. [CrossRef]

27. Pereira, L.; Mesquita, J.F. Carrageenophytes of occidental Portuguese coast: 1-spectroscopic analysis in eight carrageenophytes from Buarcos bay. Biomol. Eng. 2003, 20, 217-222. [CrossRef]

28. Soares, F.; Fernandes, C.; Silva, P.; Pereira, L.; Gonçalves, T. Antifungal activity of carrageenan extracts from the red alga Chondracanthus teedei var. lusitanicus. J. Appl. Phycol. 2016, 28, 2991-2998. [CrossRef]

29. Shannon, E.; Abu-Ghannam, N. Seaweeds as nutraceuticals for health and nutrition. Phycologia 2019, 58, 563-577. [CrossRef]

30. De Alencar, D.B.; Diniz, J.C.; Rocha, S.A.S.; Pires-Cavalcante, K.M.S.; De Lima, R.L.; De Sousa, K.C.; Freitas, J.O.; Bezerra, R.M.; Baracho, B.M.; Sampaio, A.H.; et al. Fatty acid composition from the marine red algae Pterocladiella capillacea (S. G. Gmelin) Santelices \& Hommersand 1997 and Osmundaria obtusiloba (C. Agardh) R. E. Norris 1991 and its antioxidant activity. An. Acad. Bras. Cienc. 2018, 90, 449-459. [CrossRef]

31. Kendel, M.; Wielgosz-Collin, G.; Bertrand, S.; Roussakis, C.; Bourgougnon, N.B.; Bedoux, G. Lipid composition, fatty acids and sterols in the seaweeds Ulva armoricana, and Solieria chordalis from brittany (France): An analysis from nutritional, chemotaxonomic, and antiproliferative activity perspectives. Mar. Drugs 2015. [CrossRef] [PubMed]

32. Zárate, R.; Jaber-Vazdekis, N.; Tejera, N.; Pérez, J.A.; Rodríguez, C. Significance of long chain polyunsaturated fatty acids in human health. Clin. Transl. Med. 2017, 6. [CrossRef]

33. Simopoulos, A.P. The importance of the ratio of omega-6/omega-3 essential fatty acids. Biomed. Pharmacother. 2002, 56, 365-379. [CrossRef]

34. Gonçalves, A.M.M.; Azeiteiro, U.M.; Pardal, M.A.; De Troch, M. Fatty acid profiling reveals seasonal and spatial shifts in zooplankton diet in a temperate estuary. Estuar. Coast. Shelf Sci. 2012, 109, 70-80. [CrossRef] 
35. Fomenko, S.E.; Kushnerova, N.F.; Sprygin, V.G.; Drugova, E.S.; Lesnikova, L.N.; Merzlyakov, V.Y.; Momot, T.V. Lipid Composition, Content of Polyphenols, and Antiradical Activity in Some Representatives of Marine Algae. Russ. J. Plant Physiol. 2019, 66, 942-949. [CrossRef]

36. Pereira, H.; Barreira, L.; Figueiredo, F.; Custódio, L.; Vizetto-Duarte, C.; Polo, C.; Rešek, E.; Engelen, A.; Varela, J. Polyunsaturated Fatty Acids of Marine Macroalgae: Potential for Nutritional and Pharmaceutical Applications. Mar. Drugs 2012, 10, 1920-1935. [CrossRef]

37. Schmid, M.; Guihéneuf, F.; Stengel, D.B. Fatty acid contents and profiles of 16 macroalgae collected from the Irish Coast at two seasons. J. Appl. Phycol. 2014, 26, 451-463. [CrossRef]

38. Rohani-Ghadikolaei, K.; Abdulalian, E.; Ng, W.-K. Evaluation of the proximate, fatty acid and mineral composition of representative green, brown and red seaweeds from the Persian Gulf of Iran as potential food and feed resources. J. Food Sci. Technol. 2012, 49, 774-780. [CrossRef]

39. Menaa, F.; Wijesinghe, P.A.U.I.; Thiripuranathar, G.; Uzair, B.; Iqbal, H.; Khan, B.A.; Menaa, B. Ecological and Industrial Implications of Dynamic Seaweed-Associated Microbiota Interactions. Mar. Drugs 2020, 18, 641. [CrossRef]

40. Khotimchenko, S.V.; Vaskovsky, V.E.; Titlyanova, T.V. Fatty Acids of Marine Algae from the Pacific Coast of North California. Bot. Mar. 2002, 45. [CrossRef]

41. Gosch, B.J.; Paul, N.A.; de Nys, R.; Magnusson, M. Seasonal and within-plant variation in fatty acid content and composition in the brown seaweed Spatoglossum macrodontum (Dictyotales, Phaeophyceae). J. Appl. Phycol. 2015, 27, 387-398. [CrossRef]

42. Farnham, W.F.; Fletcher, R.L.; Irvine, L.M. Attached Sargassum found in Britain. Nature 1973, 243, 2. [CrossRef]

43. Critchley, A.T.; Farnham, W.F.; Morrell, S.L. A chronology of new European sites of attachment for the invasive brownalga, Sargassum muticum, 1973-1981. J. Mar. Biol. Assoc. UK 1983, 63, 799-811. [CrossRef]

44. Rueness, J. Sargassum muticum and other introduced Japanese macroalgae: Biological pollution of European coasts. Mar. Pollut. Bull. 1989, 20, 173-176. [CrossRef]

45. Fouda, W.A.; Ibrahim, W.M.; Ellamie, A.M.; Ramadan, G. Biochemical and mineral compositions of six brown seaweeds collected from red sea at hurghada coast. Indian J. Geo-Marine Sci. 2019, 48, 484-491.

46. Lodeiro, P.; Cordero, B.; Grille, Z.; Herrero, R.; Sastre de Vicente, M.E. Physicochemical studies of Cadmium(II) biosorption by the invasive alga in Europe, Sargassum muticum. Biotechnol. Bioeng. 2004, 88, 237-247. [CrossRef] [PubMed]

47. Santos, F.; Monteiro, J.P.; Duarte, D.; Melo, T.; Lopes, D.; da Costa, E.; Domingues, M.R. Unraveling the Lipidome and Antioxidant Activity of Native Bifurcaria bifurcata and Invasive Sargassum muticum Seaweeds: A Lipid Perspective on How Systemic Intrusion May Present an Opportunity. Antioxidants 2020, 9, 642. [CrossRef] [PubMed]

48. Debbarma, J.; Madhusudana Rao, B.; Murthy, L.N.; Mathew, S.; Venkateshwarlu, G.; Ravishankar, C.N. Nutritional profiling of the edible seaweeds Gracilaria edulis, Ulva lactuca and Sargassum sp. Indian J. Fish. 2016, 63. [CrossRef]

49. Ferdouse, F.; Løvstad Holdt, S.; Smith, R.; Murúa, P.; Yang, Z. The global status of seaweed production, trade and utilization. FAO Globefish Res. Program. 2018, 124, 120.

50. Taboada, C.; Millan, R.; Miguez, I. Evaluation of marine algae Undaria pinnatifida and Porphyra purpurea as a food supplement: Composition, nutritional value and effect of intake on intestinal, hepatic and renal enzyme activities in rats. J. Sci. Food Agric. 2013, 93, 1863-1868. [CrossRef] [PubMed]

51. Araújo, R.; Vázquez Calderón, F.; Sánchez López, J.; Azevedo, I.C.; Bruhn, A.; Fluch, S.; Garcia Tasende, M.; Ghaderiardakani, F.; Ilmjärv, T.; Laurans, M.; et al. Current Status of the Algae Production Industry in Europe: An Emerging Sector of the Blue Bioeconomy. Front. Mar. Sci. 2021, 7. [CrossRef]

52. Guiry, M.D.; Guiry, G.M. AlgaeBase. World-Wide Electronic Publication, National University of Ireland, Galway. Available online: https:/ / www.algaebase.org/search/species / detail/?species_id=27676 (accessed on 11 January 2021).

53. Dellatorre, F.G.; Avaro, M.G.; Commendatore, M.G.; Arce, L.; Díaz de Vivar, M.E. The macroalgal ensemble of Golfo Nuevo (Patagonia, Argentina) as a potential source of valuable fatty acids for nutritional and nutraceutical purposes. Algal Res. 2020, 45, 101726. [CrossRef]

54. Fleurence, J.; Gutbier, G.; Mabeau, S.; Leray, C. Fatty acids from 11 marine macroalgae of the French Brittany coast. J. Appl. Phycol. 1994, 6, 527-532. [CrossRef]

55. Cofrades, S.; López-Lopez, I.; Bravo, L.; Ruiz-Capillas, C.; Bastida, S.; Larrea, M.T.; Jiménez-Colmenero, F. Nutritional and Antioxidant Properties of Different Brown and Red Spanish Edible Seaweeds. Food Sci. Technol. Int. 2010, 16, 361-370. [CrossRef]

56. Abbott, I.A.; Isabella, A.; Hollenberg, G.J. Marine Algae of California; Stanford University Press: Palo Alto, CA, USA, 1992.

57. Blackler, H. The occurrence of Colpomenia peregrina (Sauv.) Hamel in the Mediterranean (Phaeophyta, Scytosiphonales). Blumea Biodivers. Evol. Biogeogr. Plants 1967, 15, 5-8.

58. Green, L.A.; Mathieson, A.C.; Neefus, C.D.; Traggis, H.M.; Dawes, C.J. Southern expansion of the brown alga Colpomenia peregrina Sauvageau (Scytosiphonales) in the Northwest Atlantic Ocean. Bot. Mar. 2012, 55, 643-647. [CrossRef]

59. Beacham, T.A.; Cole, I.S.; DeDross, L.S.; Raikova, S.; Chuck, C.J.; Macdonald, J.; Herrera, L.; Ali, T.; Airs, R.L.; Landels, A.; et al. Analysis of Seaweeds from South West England as a Biorefinery Feedstock. Appl. Sci. 2019, 9, 4456. [CrossRef]

60. Francavilla, M.; Franchi, M.; Monteleone, M.; Caroppo, C. The red seaweed Gracilaria gracilis as a multi products source. Mar. Drugs 2013, 11, 3754-3776. [CrossRef] [PubMed] 
61. Batista, S.; Pereira, R.; Oliveira, B.; Baião, L.F.; Jessen, F.; Tulli, F.; Messina, M.; Silva, J.L.; Abreu, H.; Valente, L.M.P. Exploring the potential of seaweed Gracilaria gracilis and microalga Nannochloropsis oceanica, single or blended, as natural dietary ingredients for European seabass Dicentrarchus labrax. J. Appl. Phycol. 2020, 32, 2041-2059. [CrossRef]

62. Wilson, A.J.; Critchley, A.T. Studies on Gracilaria gracilis (Stackhouse) Steentoft, Farnham and Irvine and Gracilaria aculeata (Hering) Papenfuss from southern Africa. I. The influence of temperature, irradiance, salinity and nitrogen-nutrition on growth. South African J. Bot. 1997, 63, 465-473. [CrossRef]

63. Ben Said, R.; Mensi, F.; Majdoub, H.; Ben Said, A.; Ben Said, B.; Bouraoui, A. Effects of depth and initial fragment weights of Gracilaria gracilis on the growth, agar yield, quality, and biochemical composition. J. Appl. Phycol. 2018, 30, 2499-2512. [CrossRef]

64. Capillo, G.; Savoca, S.; Costa, R.; Sanfilippo, M.; Rizzo, C.; Lo Giudice, A.; Albergamo, A.; Rando, R.; Bartolomeo, G.; Spanò, N.; et al. New Insights into the Culture Method and Antibacterial Potential of Gracilaria gracilis. Mar. Drugs 2018, 16, 492. [CrossRef]

65. Pereira, L. Edible Seaweeds of the World; Pereira, L., Ed.; CRC Press: Boca Raton, FL, USA, 2016; ISBN 9780429154041.

66. Araujo, G.S.; Cotas, J.; Morais, T.; Leandro, A.; García-Poza, S.; Gonçalves, A.M.M.; Pereira, L. Calliblepharis jubata Cultivation Potential-A Comparative Study between Controlled and Semi-Controlled Aquaculture. Appl. Sci. 2020, 10, 7553. [CrossRef]

67. Bert, J.J.; Dauget, J.C.; Maume, D.; Bert, M. Fatty-acids and sterols of 2 red algae Calliblepharis jubata and Solieria chordalis (Gigartinales). Cryptogam. Algol. 1991, 12, 157-162.

68. Horridge, G.A. Occurrence of Asparagopsis armata harv. on the scilly Isles. Nature 1951, 167, 732-733. [CrossRef]

69. Kraan, S.; Barrington, K.A. Commercial farming of Asparagopsis armata (Bonnemaisoniceae, Rhodophyta) in Ireland, maintenance of an introduced species? J. Appl. Phycol. 2005, 17, 103-110. [CrossRef]

70. Mac Monagail, M.; Morrison, L. The seaweed resources of Ireland: A twenty-first century perspective. J. Appl. Phycol. 2020, 1-14. [CrossRef]

71. Pellegrini, M.; Pharo, P.; Sciences, F. Contribution ä etude chimique des Algues Mediterraneennes. Botanica Marina 1967, 9-14. [CrossRef]

72. Rodrigues, D.; Freitas, A.C.; Pereira, L.; Rocha-Santos, T.A.P.; Vasconcelos, M.W.; Roriz, M.; Rodríguez-Alcalá, L.M.; Gomes, A.M.P.; Duarte, A.C. Chemical composition of red, brown and green macroalgae from Buarcos bay in Central West Coast of Portugal. Food Chem. 2015, 183, 197-207. [CrossRef]

73. Milinovic, J.; Rodrigues, C.; Diniz, M.; Noronha, J.P. Determination of total iodine content in edible seaweeds: Application of inductively coupled plasma-atomic emission spectroscopy. Algal Res. 2021, 53, 102149. [CrossRef]

74. Pereira, L.; van de Velde, F. Portuguese carrageenophytes: Carrageenan composition and geographic distribution of eight species (Gigartinales, Rhodophyta). Carbohydr. Polym. 2011, 84, 614-623. [CrossRef]

75. Pereira, L.; Critchley, A.T.; Amado, A.M.; Ribeiro-Claro, P.J.A. A comparative analysis of phycocolloids produced by underutilized versus industrially utilized carrageenophytes (Gigartinales, Rhodophyta). J. Appl. Phycol. 2009, 21, 599-605. [CrossRef]

76. Levring, T.; Hoppe, H.A.; Schmid, O.J. Marinae Algae, A Survey of Research and Utilization. Fette Seifen Anstrichm. 1969, 71, 1020. [CrossRef]

77. Fujiwara-Arasaki, T.; Mino, N.; Kuroda, M. The protein value in human nutrition of edible marine algae in Japan. In Eleventh International Seaweed Symposium; Springer: Berlin, Germany, 1984; pp. 513-516.

78. Denis, C.; Morançais, M.; Li, M.; Deniaud, E.; Gaudin, P.; Wielgosz-Collin, G.; Barnathan, G.; Jaouen, P.; Fleurence, J. Study of the chemical composition of edible red macroalgae Grateloupia turuturu from Brittany (France). Food Chem. 2010, 119, $913-917$. [CrossRef]

79. Kendel, M.; Couzinet-Mossion, A.; Viau, M.; Fleurence, J.; Barnathan, G.; Wielgosz-Collin, G. Seasonal composition of lipids, fatty acids, and sterols in the edible red alga Grateloupia turuturu. J. Appl. Phycol. 2013, 25, 425-432. [CrossRef]

80. Munier, M.; Dumay, J.; Morançais, M.; Jaouen, P.; Fleurence, J. Variation in the Biochemical Composition of the Edible Seaweed Grateloupia turuturu Yamada Harvested from Two Sampling Sites on the Brittany Coast (France): The Influence of Storage Method on the Extraction of the Seaweed Pigment R-Phycoerythrin. J. Chem. 2013, 2013. [CrossRef]

81. Kendel, M.; Barnathan, G.; Fleurence, J.; Rabesaotra, V.; Wielgosz-Collin, G. Non-methylene Interrupted and Hydroxy Fatty Acids in Polar Lipids of the Alga Grateloupia turuturu Over the Four Seasons. Lipids 2013, 48, 535-545. [CrossRef]

82. Peñalver, R.; Lorenzo, J.M.; Ros, G.; Amarowicz, R.; Pateiro, M.; Nieto, G. Seaweeds as a Functional Ingredient for a Healthy Diet. Mar. Drugs 2020, 18, 301. [CrossRef] [PubMed]

83. Innis, S.M. Fatty acids and early human development. Early Hum. Dev. 2007, 83, 761-766. [CrossRef]

84. Simopoulos, A.P. Omega-3 Fatty Acids in Inflammation and Autoimmune Diseases. J. Am. Coll. Nutr. 2002, 21, 495-505. [CrossRef]

85. Yazici, Z.; Aysel, V.; Öksüz, E.; Köse, A.; Cumali, S.; Güven, K.C. Fatty acid composition of marine macroalgae from the Black Sea and Dardanelles. Toxicol. Environ. Chem. 2007, 89, 371-379. [CrossRef]

86. Soler-Vila, A.; Coughlan, S.; Guiry, M.D.; Kraan, S. The red alga Porphyra dioica as a fish-feed ingredient for rainbow trout (Oncorhynchus mykiss): Effects on growth, feed efficiency, and carcass composition. J. Appl. Phycol. 2009, 21, 617-624. [CrossRef]

87. Norambuena, F.; Hermon, K.; Skrzypczyk, V.; Emery, J.A.; Sharon, Y.; Beard, A.; Turchini, G.M. Algae in Fish Feed: Performances and Fatty Acid Metabolism in Juvenile Atlantic Salmon. PLoS ONE 2015, 10, e0124042. [CrossRef]

88. EFSA Panel on Dietetic Products, Nutrition and Allergies (NDA). Scientific Opinion related to the Tolerable Upper Intake Level of eicosapentaenoic acid (EPA), docosahexaenoic acid (DHA) and docosapentaenoic acid (DPA). EFSA J. 2012, 10, 2815. [CrossRef] 
89. Institute of Medicine of the National Academies. Dietary Reference Intakes for Energy, Carbohydrate, Fiber, Fat, Fatty Acids, Cholesterol, Protein and Amino Acids. 2005. Available online: https://www.nal.usda.gov/sites/default/files/fnic_uploads/ energy_full_report.pdf (accessed on 30 April 2021).

90. Simopoulos, A.P.; DiNicolantonio, J.J. The importance of a balanced $\omega-6$ to $\omega-3$ ratio in the prevention and management of obesity. Open Hear. 2016, 3, e000385. [CrossRef]

91. DiNicolantonio, J.J.; O'Keefe, J.H. Importance of maintaining a low omega-6/omega-3 ratio for reducing inflammation. Open Hear. 2018, 5, e000946. [CrossRef]

92. Joint FAO/WHO Expert Consultation. Fats and Fatty Acids in Human Nutrition. Ann. Nutr. Metab. 2008, 55.

93. Simopoulos, A.P. The Importance of the Omega-6/Omega-3 Fatty Acid Ratio in Cardiovascular Disease and Other Chronic Diseases. Exp. Biol. Med. 2008, 233, 674-688. [CrossRef]

94. Lee, J.H.; Fukumoto, M.; Nishida, H.; Ikeda, I.; Sugano, M. The Interrelated Effects of n-6/n-3 and Polyunsaturated/Saturated Ratios of Dietary Fats on the Regulation of Lipid Metabolism in Rats. J. Nutr. 1989, 119, 1893-1899. [CrossRef]

95. van Ginneken, V.J.; Helsper, J.P.; de Visser, W.; van Keulen, H.; Brandenburg, W.A. Polyunsaturated fatty acids in various macroalgal species from north Atlantic and tropical seas. Lipids Health Dis. 2011, 10, 104. [CrossRef] [PubMed]

96. Saito, M.; Kubo, K. Relationship between tissue lipid peroxidation and peroxidizability index after $\alpha$-linolenic, eicosapentaenoic, or docosahexaenoic acid intake in rats. Br. J. Nutr. 2003, 89, 19-28. [CrossRef]

97. Roque, B.M.; Salwen, J.K.; Kinley, R.; Kebreab, E. Inclusion of Asparagopsis armata in lactating dairy cows' diet reduces enteric methane emission by over 50 percent. J. Clean. Prod. 2019, 234, 132-138. [CrossRef]

98. Kolb, N.; Vallorani, L.; Milanovi'c, N.; Stocchi, V. Evaluation of Marine AlgaeWakame (Undaria pinnatifida) and Kombu (Laminaria digitata japonica) as Food Supplements. Food Technol. Biotechnol. 2004, 42, 57-61. 